\title{
A Survey on English Learning for the Majors of International Business under the Background of Globalization
}

\author{
Hengbo Yang \\ Qujing Normal University, QJU, Qujing, China \\ 1184603907@qq.com
}

Keywords: English learning; Practical ability; Gobalization

\begin{abstract}
With the development of the globalization, English as a global language has become more and more important in all aspects. As for the students majoring in international business, there is no any doubt that English is viewed as an important subject in the curriculum of the school. Therefore, in order to improve students' practical ability of English, in particular, business English, the paper aims at finding out how to better their understanding of English through the questionnaire so that they will have a successful learning outcome at school.
\end{abstract}

\section{Introduction}

As humans enter the new era, everything is changing with the development of the globalization. In recent years, the reform of education has stirred many changes for the curriculum in the universities. That is to say, many new disciplines have emerged, which challenges the instructors and students. For example, as the economy has been globalized, business becomes a focus of the whole world. This has challenged the reform of education that must be adjusted to meet the requirements of higher learning. Throughout the whole world, course design and syllabus are readjusted to be in accordance with the social needs. In American universities, such reform was conducted ahead of other countries, which laid a solid ground for the development of globalization. In China, universities are following the trends that have initiated course design. Some business schools have been established in universities. However, there is a problem emerging. That is how students can learn the business course well in English. Because international business requires students to have a good mastery of both professional courses and English. Under this background, it is necessary to make a study of students majoring in international business who are cultivated to have English proficiency in their present and future career. In learning, it is important to realize the fact that culture and language are intertwined and shape each other. Language is not a matter of neutral codes and grammatical rules. Each time we select words, form sentences, and send a message, either oral or written, we also make cultural choices. Therefore, for students majoring the international business, cultural knowledge is highly emphasized so that they can understand difference in foreign situations and can handle those problems appropriately.

\section{The Current Situations of Educational Background of the Students}

The international business as a major is a newly subject designed for the students who are intended to work in the business field after graduation. In Qujing Normal University, it is the first students who have registered themselves in the international business. In 2015, the International College had its first students whose number was 67. In 2016, the second students were admitted to the number of 98. Now there are more than 170 students whose major is international business. The students are from different parts of China, some are from North China, some from East, some from North. The different regions represent the different origins of students in Chinese mainland, which reflects the popularity of enrollment in the university. According to the statistics, $90 \%$ of students are from the underdeveloped areas where the economy is going very slowly. Only $10 \%$ of students are from the good economic situations of the family. Based on the great difference of family income, there is a 
problem that students will find it hard to study abroad in terms of tuition. In dealing with this, university has released some policies that are effective in making students realize their dreams. One of them is reaching an agreement with universities in Thailand by offering some part-time jobs for students to earn money that can alleviate their living expenditure. On the other hand, students are getting loans from the bank if they are able to repay in a given time. In addition to financial issue, students of international business are required to devote themselves to language learning. The International College has set up a proper platform and offered some learning resources for students. For example, some foreign teachers have been invited from the US and Thailand to teach English and Thai. Under the circumstances of natural language, students are obtaining much chance to practice their English. At present, 80\% of the sophomores are able to use English in an appropriate way. The ability of using English can be found in their daily conversation and the participation of various activities and competitions as well as their understanding of professional courses in English like human resources, management.

\section{The Teaching Methods Used in the English Classroom}

Language learning is crucial key for learners and teachers to consider in order to develop students' language competency. In the classroom, teachers tend to deal with a group of students at one time, but language learning occurs differently in different individuals. Therefore, one teaching methods works for some students, while that teaching methods may not work for other students. Many researchers have tried to reveal what kinds of factors affect the favored language use. Different factors, such as age, motivation, nationality, gender and so on are related to different uses of language learning.

For the purpose of improving the competence and performance of English learning, some measures have been taken to achieve the goals. There are different methods used among the teachers duo to different topics. Based on the attending lectures, a popular way of teaching English is the communicative approach that focuses on the interactions between teachers and students. The communicative approach has facilitated students to engage themselves in discussing, sharing, and understanding the points. This, in some degrees, has made English learning more interesting and more practical. Within one semester' instruction, a positive outcome has been produced.

\section{The Data Collection and Analysis of Conducting Questionnaire}

The survey used mixed methods in order to identify the use of language for the business majors. Data were collected from the freshman and sophomore to support the result of the investigation. The survey has been conducted among the students whose major is international business. There are 105 participants completing the questionnaire containing 29 questions. Each question is focusing on the motivation of students in English learning from different aspects like interests, expectations, studying abroad, knowledge accumulation, job-hunting, travelling, etc.

Based on the data analysis, the result of questionnaire is listed as follows. For the first question, there are $62.8 \%$ of 105 students expressing their views that English as a global language is very important. This reflects the fact that a great majority of students pay much attention to English learning. For the second question, it is very exciting to find that there are $95 \%$ of students who will learn English. This greatly tells that English as a compulasary course is imperative and practical in universities. From question 3 to 10, the percentage is different in reflecting students having variour ideas on English learning. In terms of passing the English tests, 36\% of students tend to think that they study English for passing the CET 4 and CET6, which means that they just consider the importance of getting certificate instead of the use of language. From question 11 to question 16, students don't think that they are proud of learning English. They don't want to be recongnized or accepted by others in terms of English learning. From question 17 to question 21, the percentage is 
not high in terms of admiring those stars or enjoying movies, which implies that they have no such passion from learning English. However, in answering question 22, the high percentage reflects $40 \%$ of students enjoy English learning for the purpose of finding a good job in the future. It is a good thing that when answering question 28, a great majority of students are interested in learning English for the sake of broadening their mind and enriching themselves.

Table 1 Basic Information

\begin{tabular}{|c|c|}
\hline Sex & B.Female \\
\hline Grade & C.junior D.senior \\
\hline English achievemrnts & A. above 120 \\
\hline Hours spent in English & $\begin{array}{l}\text { A.more than } 2 \quad \text { B.1-2 C. Below } 1 \\
\text { D.a littel befor the test }\end{array}$ \\
\hline $\begin{array}{l}\text { Communicating with } \\
\text { foreigners }\end{array}$ & C.occasionaly \\
\hline $\begin{array}{l}\text { Evaluation of English } \\
\text { level }\end{array}$ & $\begin{array}{l}\text { A.wonderful } \quad \text { B.ordinary } \quad \text { C.just so so } \\
\text { bad }\end{array}$ \\
\hline $\begin{array}{l}\text { The most difficulty in } \\
\text { English learning }\end{array}$ & B.reading ability \\
\hline Daily communication & D.rote memorization \\
\hline $\begin{array}{l}\text { The first time of } \\
\text { learning English }\end{array}$ & $\begin{array}{l}\text { A.Kindergarten B.first grade of primary school C.thethird } \\
\text { to the fouth grade of primary school D.junior high school }\end{array}$ \\
\hline $\begin{array}{l}\text { The interest of learning } \\
\text { English }\end{array}$ & C.enjoy less D.dislike \\
\hline
\end{tabular}

\section{Motivation}

Table 2 There are six items representing opinnios in terms of learning motivation. Please choose the one that expresses your ideas of English learning.

\begin{tabular}{|l|c|c|c|c|c|c|}
\hline \multicolumn{1}{|c|}{ The reason of English learning } & \multicolumn{7}{c|}{ Degree of recongnition } \\
\hline $\begin{array}{l}\text { 1.English is a global language that helps me to } \\
\text { understand the world better. }\end{array}$ & 1 & 2 & 3 & 4 & 5 & 6 \\
\hline $\begin{array}{l}\text { 2.English is a compulsary course which is } \\
\text { required to learn. }\end{array}$ & 1 & 2 & 3 & 4 & 5 & 6 \\
\hline 3.For getting graduation diploma & 1 & 2 & 3 & 4 & 5 & 6 \\
\hline 4.For learning all courses well & 1 & 2 & 3 & 4 & 5 & 6 \\
\hline 5.For meeting the expectations of parents & 1 & 2 & 3 & 4 & 5 & 6 \\
\hline 6.For passing the teast as CET-4. & 1 & 2 & 3 & 4 & 5 & 6 \\
\hline $\begin{array}{l}\text { 7.For passing the test like TOEFL and studying } \\
\text { abroad . }\end{array}$ & 1 & 2 & 3 & 4 & 5 & 6 \\
\hline $\begin{array}{l}\text { 8.For hunting a good job with the English } \\
\text { certificate }\end{array}$ & 1 & 2 & 3 & 4 & 5 & 6 \\
\hline $\begin{array}{l}\text { 9.I should study English like my classmates and } \\
\text { friends. }\end{array}$ & 1 & 2 & 3 & 4 & 5 & 6 \\
\hline 10.For getting scholarship & & & & & & \\
\hline
\end{tabular}


Table 2 cont.

\begin{tabular}{|c|c|c|c|c|c|c|}
\hline 11.For travelling in foreign countries & 1 & 2 & 3 & 4 & 5 & 6 \\
\hline $\begin{array}{l}\text { 12.For participating different English } \\
\text { competitions and winning the prizes. }\end{array}$ & 1 & 2 & 3 & 4 & 5 & 6 \\
\hline $\begin{array}{l}\text { 13.For getting good scores in the future in the } \\
\text { graduate test }\end{array}$ & 1 & 2 & 3 & 4 & 5 & 6 \\
\hline $\begin{array}{l}\text { 14.Learning English is a proud thing thatcan be } \\
\text { recongnized and approved }\end{array}$ & 1 & 2 & 3 & 4 & 5 & 6 \\
\hline $\begin{array}{l}\text { 15.I like my English teachers because of the good } \\
\text { teaching methods. }\end{array}$ & 1 & 2 & 3 & 4 & 5 & 6 \\
\hline 16.My English teacher always encourages me. & 1 & 2 & 3 & 4 & 5 & 6 \\
\hline $\begin{array}{l}\text { 17.My English is not good but I am confident to } \\
\text { learn it well. }\end{array}$ & 1 & 2 & 3 & 4 & 5 & 6 \\
\hline $\begin{array}{l}\text { 18. When speaking English, I feel happy and } \\
\text { proud. }\end{array}$ & 1 & 2 & 3 & 4 & 5 & 6 \\
\hline $\begin{array}{l}\text { 19.I like challenge. I want to prove my ability by } \\
\text { learning English well. }\end{array}$ & 1 & 2 & 3 & 4 & 5 & 6 \\
\hline $\begin{array}{l}\text { 20.I admire those stars because they can speak } \\
\text { very good English. }\end{array}$ & 1 & 2 & 3 & 4 & 5 & 6 \\
\hline $\begin{array}{l}\text { 21.I want to catch up those whose English is very } \\
\text { good. }\end{array}$ & 1 & 2 & 3 & 4 & 5 & 6 \\
\hline $\begin{array}{l}\text { 22.Learning English well will create much } \\
\text { opportunities for my work. }\end{array}$ & 1 & 2 & 3 & 4 & 5 & 6 \\
\hline $\begin{array}{l}\text { 23.I want to make a great achievement inEnglish } \\
\text { learning. }\end{array}$ & 1 & 2 & 3 & 4 & 5 & 6 \\
\hline $\begin{array}{l}\text { 24.Learning English is helpful for me to surf on } \\
\text { the intenet or to program.. }\end{array}$ & 1 & 2 & 3 & 4 & 5 & 6 \\
\hline 25.I have my interest in foregn film, literature. & 1 & 2 & 3 & 4 & 5 & 6 \\
\hline $\begin{array}{l}\text { 26.For understanding the foreign mass media and } \\
\text { the current events. }\end{array}$ & 1 & 2 & 3 & 4 & 5 & 6 \\
\hline $\begin{array}{l}\text { 27.For better understanding of the development of } \\
\text { technology and economy. }\end{array}$ & 1 & 2 & 3 & 4 & 5 & 6 \\
\hline $\begin{array}{l}\text { 28.Learning English can develop my major which } \\
\text { is practical in conducting international business } \\
\text { and trade. }\end{array}$ & 1 & 2 & 3 & 4 & 5 & 6 \\
\hline $\begin{array}{l}\text { 29.Learning English can brodern my visions and } \\
\text { enrich myself. }\end{array}$ & 1 & 2 & 3 & 4 & 5 & 6 \\
\hline 30.For making friends from the world & 1 & 2 & 3 & 4 & 5 & 6 \\
\hline $\begin{array}{l}\text { 31.Speakinbg fluent English means good } \\
\text { education and rich knowledge. }\end{array}$ & 1 & 2 & 3 & 4 & 5 & 6 \\
\hline
\end{tabular}

\section{Conclusion}

English as a global language has its influential role in the development of the ecommerce globalization. Students specializing the international business should be aware of the value of English under this background. With the survey, it strongly shows that in universities, English as a compulsory subject, is beneficial to motivate students in enhancing their views of understanding the 
trends of the world economy. Therefore, English classroom teaching will facilitate the combination of both language and culture.

\section{References}

[1] Andrews, James R. Public Speaking: Principles into Practice. New York: Macmillian Publishing Company, 1987.

[2] Davis, L. Doing Culture: Cross-Cultural Communication in Action. Beijing: Foreign Language Teaching and Research Press

[3] Tomalin, B. Stempleski: Cultural Awareness Oxford: Oxford University, 1993.

[4] Varner, I.\&L.Beamer. Intercultural Communication in the Global Workplace (3rd ed.) McGrawHill Companies, Inc., 2005. 